\title{
Relationship Between Teachers Educational Qualifications And Student's Achievement In Chemistry: A Case Study Of Owerri West LGA
}

\author{
Unanma, A. O. ${ }^{1}$, Abugu, H. O. ${ }^{2}$, Dike, R. C. ${ }^{3}$ and Umeobika U. C. ${ }^{2}$ \\ ${ }_{1}^{1}$ (Department of Educational psychology, Imo State University, Owerri, Imo State, Nigeria) \\ ${ }_{2}^{2}$ (Department of Pure and Industrial Chemistry, Nnamdi Azikiwe University Awka, Anambra) State, Nigeria \\ ${ }_{3}^{3}$ (Chemistry Department Alvana Model Secondary School, Imo State, Nigeria)
}

\begin{abstract}
This study examined the relationship between Teacher's academic qualifications and academic achievement of Senior Secondary school Students in Chemistry. The area for the study was Owerri West LGA. A case study of four secondary schools formed the research design. Teacher's academic qualifications and the SS I student's third term result formed the data which was analysed using simple percentage and Pearson Correlation. Three research questions were answered and the findings of the research reviewed that there is a positive relationship between the teacher's academic qualifications and student's academic achievement. Since teachers professional qualification influences students academic achievement in Chemistry, the government and all stakeholders in education sector should endeavour to implement its policy on basic education for all and thus, create an enlightened society in which every Chemistry teacher would be educated enough to have a positive influence on their Chemistry students for better achievement in the subject.
\end{abstract}

Key words: relationship, academics, performance, achievement, teachers.

\section{Introduction}

The differential scholastic achievement of students in Nigeria has been and is still a source of concern and research interest to educators, government and parents. This is so because of the great importance that education has on the national development of the country. All over the country, there is a consensus of opinion about the fallen standard of education in Nigeria (Adebule, 2004). Parents and government are in total agreement that their huge investment on education is not yielding the desired dividend. Teachers also complain of students' low performance at both internal and external examinations. The annual releases of Senior Secondary Certificate Examination results (SSCE) conducted by West African Examination Council (WAEC) justified the problematic nature and generalization of poor secondary school students' performance in different school subjects. For instance, the percentage of failure compared with students who passed English and Mathematics between 2004 to 2007 are shown in tables 1 and 2.

Poor academic performance according to Aremu (2003) is a performance that is adjudged by the examinee/testee and some other significant as falling below an expected standard. Poor academic performance has been observed in school subjects especially mathematics, chemistry and English language among secondary school students (Adesemowo, 2005). Aremu (2000) stresses that academic failure is not only frustrating to the students and the parents, its effects are equally grave on the society in terms of dearth of manpower in all spheres of the economy and politics. Education at secondary school level is supposed to be the bedrock and the foundation towards higher knowledge in tertiary institutions. It is an investment as well as an instrument that can be used to achieve a more rapid economic, social, political, technological, scientific and cultural development in the country. The National Policy on Education (2004) stipulated that secondary education is an instrument for national development that fosters the worth and development of the individual for further education and development, general development of the society and equality of educational opportunities to all Nigerian children, irrespective of any real or marginal disabilities.

The role of secondary education is to lay the foundation for further education and if a good foundation is laid at this level, there are likely to be no problem at subsequent levels. However, different people at different times have passed the blame of poor performance in secondary school to students because of their low retention, parental factors, association with wrong peers, low achievement, low retention, low achievement motivation and the likes (Aremu \& Sokan, 2003; Aremu \& Oluwole 2001; Aremu, 2000).

Morakinyo (2003) believe that the falling level of academic achievement is attributable to teacher's non-use of verbal reinforcement strategy. Others found out that the attitude of some teachers to their job is reflected in their poor attendance to lessons, lateness to school, unsavoury comments about student's performance that could damage their ego, poor method of teaching and the likes affect pupils' academic performance. 
The question therefore is what is the cause of this fallen standard and poor academic performance of students? Is the fault entirely that of teachers or students or both of them? Is it that students of today are nonachievers because they have low intelligent quotient and a good neutral mechanism to be able to act purposefully, think rationally and deal effectively with academic tasks? Or is it because teachers are no longer putting in much commitment as before? Or is it in teachers' method of teaching and interaction with pupils? Or is the poor performance of students caused by parents' neglect, separation and poverty? The present study therefore sought to find out the relationship between teachers' qualification and student's academic achievement in chemistry in Owerri West LGA.

\section{Statement of the Problem}

Based on this background, and the poor performance of students in external examinations as exemplified in tables $\mathrm{i}$ and ii, the central problem of this study is that secondary school students perform poorly in both internal and external examinations particularly in chemistry.

Table i: The West African Examinations Council (WAEC) Performance in the Senior School Certificate Examinations: May/June, 2004-2007: Mathematics

\begin{tabular}{|l|l|l|l|l|}
\hline YEAR & TOTAL NO OF & CREDIT A1-C6 & PASS P7-P8 & FAIL F9 \\
\cline { 3 - 5 } & CANDIDATE & $\%$ & $\%$ & $\%$ \\
\hline 2004 & 1019524 & 33.97 & 28.16 & 34.47 \\
2005 & 1054853 & 38.20 & 25.36 & 34.41 \\
2006 & 1149277 & 41.12 & 31.09 & 24.95 \\
2007 & 1249028 & 46.75 & 26.72 & 24.24 \\
\hline
\end{tabular}

Source: Statistics Office, WAEC, Lagos, Nigeria. (2009)

Table ii: The West African Examinations Council (WAEC) Performance in the Senior School Certificate Examinations: May/June, 2004-2007: English

\begin{tabular}{|l|l|l|}
\hline \multirow{2}{*}{ YEAR } & CREDIT A1-C6 & FAIL F9 \\
\cline { 2 - 3 } & \% & \% \\
\hline 2004 & 29.59 & 37.61 \\
2005 & 25.36 & 36.93 \\
2006 & 34.48 & 29.65 \\
2007 & 29.94 & 26.54 \\
\hline
\end{tabular}

Source: Statistics Office, WAEC, Lagos, Nigeria. (2009)

This poor performance has generated a lot of concern amongst stakeholders in education business. As a result, this study sought to investigate the extent to which teacher's academic qualifications affect student's academic achievement in chemistry.

\section{Purpose of the Study}

The study sets out clearly among other things to find out, if there is a relationship between teacher's qualification and academic achievement of students in Owerri West LGA. Specifically this study will find out 1. The academic qualifications of chemistry teachers in Owerri west LGA Secondary Schools.

2. The level of academic achievement of students offering chemistry in senior secondary schools in Owerri West LGA.

3. If there is a relationship between the academic qualifications of chemistry teachers and students academic achievement in senior secondary schools in Owerri West LGA.

\subsection{Research Design}

\section{Method}

A correlational research design which seeks to find out the relationship between the academic qualification of teachers and academic achievement of students in Owerri West LGA was used in this study.

\subsection{Area of the Study}

The area of this study is Owerri West local Government area. The local government area is bounded by Owerri North, Owerri Municipal and Mbaitoli LGA. Its dwellers are mostly civil servants, traders, farmers, craftsmen and unskilled workers. 


\subsection{Population of the study}

The population for this study comprises of all senior secondary school students (SSI) in Owerri West LGA of Imo state, who have written their third term examination in chemistry. There are 11 Imo state owned secondary school in Owerri West LGA, with a total population of 545 (five hundred and fourty five) SSI students (SEMD, 2012). A total of 250 SS I students and 18 chemistry teachers from four secondary schools were used for the study

\subsection{Sampling and Sampling Techniques}

A random sampling technique was used to select four schools out of the 12 secondary schools in Owerri West LGA. The 12 schools were written in a small piece of papers with numbers assigned to each school and the paper was folded to conceal the numbers and placed in a container. The container was shuffled and four pieces of the paper was picked randomly to select four schools.

\subsection{Instruments for Data Collection}

In order to gather information needed for this study, the sources of the data was purely from checklist. The data for this study consisted of grades of students in SSI Class and their chemistry teacher's qualifications. The results were collected from the respective offices of the principals of the above selected schools.

\subsection{Methods of Data Analysis}

In analysing data gathered for this study, the researcher employed a descriptive statistic by the use of percentages and mean. The qualification of teachers from the various sampled schools will be shown according to their type of certificate/degree while student's academic achievements will be grades into pass or fail and expressed in simple percentage. Student's academic achievement is shown with percentages and mean. Pearson product moment correlational coefficient was used to establish the relationship between teacher's academic qualification and student's academic achievement in chemistry. Teacher's qualification was graded and the proportion of each grade worked out.

\section{Result}

Research Question 1: What are the academic qualifications of chemistry teachers in Owerri West LGA? This research question is answered by Table 3, which gives the academic qualifications of chemistry teachers in the sampled schools

Table iii: Qualification of Chemistry Teachers in the sampled Schools

\begin{tabular}{|l|l|l|l|l|l|l|l|}
\hline \multicolumn{9}{|c|}{$\begin{array}{l}\text { Qualification and number of Chemistry } \\
\text { Teachers }\end{array}$} \\
\hline S/n & Name of School & Ph.D. & M.Sc (Ed) & PGDE & B.Sc (Ed) & HND & NCE \\
\hline 1 & A & - & - & - & 2 & - & - \\
\hline 2 & B & - & - & - & 2 & - & - \\
\hline 3 & C. & - & - & 1 & 2 & - & - \\
\hline 4 & D & - & 3 & - & - & - & - \\
\hline
\end{tabular}

Table iii shows that chemistry teachers in the selected schools posses at least a minimum of first degree in chemistry.

Research question 2: What is the academic achievement of chemistry students in Owerri West LGA? This research question is answered by a table showing the percentage of pass or fail and the mean of the academic achievement of chemistry students in the sampled schools

Table iv: Academic Achievements of School A

\begin{tabular}{|c|c|c|c|c|c|}
\hline & & & SS I & & Mean Score \\
\hline $\mathrm{S} / \mathrm{N}$ & Score Range & Grade & $\begin{array}{l}\text { Number of } \\
\text { Students }\end{array}$ & $\%$ & \multirow{8}{*}{48.4} \\
\hline 1 & $0-39$ & $\mathrm{~F}$ & 17 & 42.5 & \\
\hline 2 & $40-44$ & $\mathrm{E}$ & 4 & 10.0 & \\
\hline 3 & $45-49$ & $\mathrm{D}$ & 2 & 5.00 & \\
\hline 4 & $50-64$ & $\mathrm{C}$ & 4 & 10.0 & \\
\hline 5 & $65-69$ & $\mathrm{~B}$ & 1 & 2.50 & \\
\hline 6 & $70-100$ & A & 12 & 30.0 & \\
\hline TOTAL & & & 40 & $100 \%$ & \\
\hline
\end{tabular}


Table v: Academic Achievements of School B

\begin{tabular}{|c|c|c|c|c|c|}
\hline & & & & & Mean \\
\hline $\mathrm{S} / \mathrm{N}$ & Score Range & Grade & $\begin{array}{l}\text { Number of } \\
\text { Students }\end{array}$ & $\%$ & \\
\hline 1 & $0-39$ & $\mathrm{~F}$ & 15 & 30.61 & \\
\hline 2 & $40-44$ & $E$ & 7 & 14.29 & 46.3 \\
\hline 3 & $45-49$ & $\mathrm{D}$ & 5 & 10.20 & \\
\hline 4 & $50-64$ & $\mathrm{C}$ & 3 & 6.12 & \\
\hline 5 & $65-69$ & $\mathrm{~B}$ & 5 & 10.20 & \\
\hline 6 & $70-100$ & A & 14 & 28.57 & \\
\hline TOTAL & & & 49 & $100 \%$ & \\
\hline
\end{tabular}

Table vi: Academic Achievements of School C

\begin{tabular}{|c|c|c|c|c|c|}
\hline & & \multicolumn{3}{|c|}{ SS I } & Mean \\
\hline S/N & Score Range & Grade & $\begin{array}{l}\text { Number of } \\
\text { Students }\end{array}$ & $\%$ & \\
\hline 1 & $0-39$ & $\mathrm{~F}$ & 0 & 0.00 & \\
\hline 2 & $40-44$ & $\mathrm{E}$ & 10 & 16.13 & 57.3 \\
\hline 3 & $45-49$ & $\mathrm{D}$ & 11 & 17.74 & \\
\hline 4 & $50-64$ & $\mathrm{C}$ & 10 & 16.13 & \\
\hline 5 & $65-69$ & B & 18 & 29.03 & \\
\hline 6 & $70-100$ & A & 13 & 20.97 & \\
\hline TOTAL & & & 62 & $100 \%$ & \\
\hline
\end{tabular}

Table vii: Academic Achievements of School D

\begin{tabular}{|c|c|c|c|c|c|}
\hline & & \multicolumn{3}{|c|}{ SS I } & Mean \\
\hline $\mathrm{S} / \mathrm{N}$ & Score Range & Grade & $\begin{array}{l}\text { Number of } \\
\text { Students }\end{array}$ & $\%$ & \multirow{8}{*}{65.2} \\
\hline 1 & $0-39$ & $\mathrm{~F}$ & 2 & 2.02 & \\
\hline 2 & $40-44$ & $E$ & 15 & 15.15 & \\
\hline 3 & $45-49$ & $\mathrm{D}$ & 18 & 18.18 & \\
\hline 4 & $50-64$ & $\mathrm{C}$ & 14 & 14.14 & \\
\hline 5 & $65-69$ & B & 20 & 20.20 & \\
\hline 6 & $70-100$ & $\mathrm{~A}$ & 30 & 30.30 & \\
\hline TOTAL & & & 99 & $100 \%$ & \\
\hline
\end{tabular}

The summary of student's achievement in tables iv, v, vi and vii shows that chemistry students in the sampled schools had more than $50 \%$ and mean scores of 48.3, 46.3, 57.3 and 65.2 respectively.

Research question 3: Is there a relationship between teachers academic qualifications and students academic achievement in chemistry? This is answered by a table which gives the product moment correlational coefficient of teacher's academic qualification and mean of student's academic achievement in chemistry.

Table viii: Teacher's Academic Qualification and Student's Mean Academic Achievement in Chemistry

\begin{tabular}{|l|l|l|l|l|l|l|}
\hline S/n & Name of school & Teacher qualification & Grade & Proportion & $\begin{array}{l}\text { Student's } \\
\text { mean score }\end{array}$ & $\begin{array}{l}\text { Product } \\
\text { Moment } \\
\text { Coefficient }\end{array}$ \\
\hline 1 & A & BSc(ed) & 3 & 50 & 48.4 & \\
\hline 2 & B & BSc(ed) & 3 & 50 & 46.3 & \multirow{2}{*}{0.95} \\
\hline 3 & C & PGDE, BSc(ed) & 3,4 & 59 & 57.3 & \\
\hline 4 & D & MSc(ed) & 5 & 83 & 65.2 & \\
\hline
\end{tabular}

Decision: if the coefficient is equal to (1), there is a perfect positive correlation, that is, a change in one variable leads to a change in another variable (Akuezuilo and Agu, 2003). 
Summarily therefore, there is a strong linear relation between teachers academic qualifications and students academic achievement in chemistry in Owerri West LGA, Imo State.

\section{Discussion and Conclusion}

The findings of this study revealed that chemistry teachers in Owerri West LGA had the required professional qualifications to teach chemistry and there is a perfect positive relationship between teachers qualification and students academic achievement in chemistry. This finding is in line with that of Asikhia (2010) and Umar-ud-Din et al (2010) who in their study showed that teachers' qualification influences student's academic performance. This is not in line with the findings of Dahar et al (2011) who observed in a similar study that there is no much difference in teacher quality and student academic achievement in school subjects. Teachers with higher qualification are in a better position to lead students to achieve more, as they are equipped with the pedagogical content knowledge to teach their subjects. Also teachers who continually update their knowledge by further degrees will be able to manipulate the learning environment and process to make learning easier for their students.

This research also revealed that students achieve more when exposed to better learning conditions and much more qualified teachers as shown in table 8. This is in line with the findings of Agyeman (1993) who noted that teachers who do not have any of the academic and the professional teaching qualification would certainly have a negative influence on the teaching and learning of their subject.

\section{Conclusion}

The enormity and consequence of poor academic achievement call for a serious concern. The more reason why scholars have not ceased to turn their research beam light on the subject matter. The learning of chemistry depends on the way it is presented to the learner, the way the learner actively interacts with the learning experiences presented to him and the environment within which the learning takes place. With the current increase in scientific knowledge the world over, much demand is placed and emphasis is laid on the teacher, the learner and the environment in the whole process of teaching and learning of chemistry.

The study found that professional qualification has a positive relationship with academic achievement of Senior Secondary School students in Chemistry within Owerri West LGA.

\section{References}

[1] S. O. Adebule, Gender differences on a locally standardized anxiety rating scale in mathematics for Nigerian secondary schools in Nigerian. Journal of Counselling and Applied Psychology. 1, 2004, 22-29.

[2] P. O. Adesemowo, Premium on affective education: panacea for scholastic malfunctioning and aberration. 34th Inaugural Lecture, Olabisi Onabanjo University. Ago-Iwoye: Olabisi Onabanjo University Press. 2005

[3] D. K. Agyeman, Sociology of education for African students. Accra: Black Mask Ltd. 1993

[4] E.O Akuezuilo, \& N. Agu, Research and Statistics in Education and Social Science. Nuel Centi Publishers, Awka.Mellenium Edition. 2003 O. Aremu, Academic performance 5 factor inventory. Ibadan: Stirling-Horden Publishers. 2000

[5] A.O. Aremu, \& D.A. Oluwole, Gender and birth order as predictors of normal pupil's anxiety pattern in examination. Ibadan Journal of Educational Studies, 1, (1), 2001, 1-7.

[6] O. A Aremu, \& B. O. Sokan, A multi-causal evaluation of academic performance of Nigerian learners: issues and implications for national development. Department of Guidance and Counselling, University of Ibadan, Ibadan. 2003.

[7] O. A. Asikhia, Students and Teachers' Perception of the Causes of Poor Academic Performance in Ogun State Secondary Schools [Nigeria]: Implications for Counselling for National Development. European Journal of Social Science. 13, 2 (2010).

[8] Federal Republic of Nigeria National Policy on Education. (Revised Edition). Lagos: Federal Ministry of Education. 2004.Morakinyo, Relative efficacy of systematic desensitization, self statement monitoring and flooding on subjects test anxiety. Unpublished Phd. Thesis. University of Ibadan. 2003

[9] Muhammad Arshad Dahar, Rashida Ahmad Dahar, Riffat Tahira Dahar, Fayyaz Ahmad Faize, Impact of Teacher Quality on the Academic Achievement of Students at Secondary Stage in Punjab (Pakistan). European Journal of Social Sciences. 19, 1, 2011.

[10] State Education Management Board, Imo state Nigeria (2011).

\section{APPENDIX 1}

Calculation of Pearson Correlation

\begin{tabular}{|l|l|l|l|l|l|}
\hline S/N & $\begin{array}{l}\text { Teacher's Qualification } \\
\text { Grade }(\mathrm{X})\end{array}$ & $\begin{array}{l}\text { Mean score } \\
(\mathrm{Y})\end{array}$ & $\mathrm{XY}$ & $\mathrm{X}^{2}$ & $\mathrm{Y}^{2}$ \\
\hline 1 & 50 & 48.4 & 2420 & 2500 & 2343 \\
\hline 2 & 50 & 46.3 & 2315 & 2500 & 2144 \\
\hline 3 & 116 & 57.3 & 6647 & 13456 & 3283 \\
\hline 4 & 83 & 65.2 & 5412 & 6889 & 4251 \\
\hline Total & 299 & 217.2 & 16794 & 25345 & 12021 \\
\hline
\end{tabular}

$\mathrm{A}=3 / 6 \times 100=50$

$\mathrm{B}=3 / 6 \times 100=50$ 
$\mathrm{C}=7 / 6 \times 100=116$

$\mathrm{D}=5 / 6 \times 100=83$

Product Moment Correlation Coefficient $(\mathrm{r})=$

Where $\mathrm{r}=$ Pearson $\mathrm{r}$

$$
\sqrt{\left[N \sum X^{2}\right.} \frac{\left.\frac{N}{-\left(\sum X Y-\sum X \sum Y\right.} 2\right]\left[N \sum Y^{2}\right.}{\left.-\left(\sum Y\right)^{2}\right]}
$$

$\sum X=$ Sum of Grades of teacher's Qualification

$\sum \mathrm{Y}=$ Sum of Mean score of students

$\mathrm{N}=$ Number of schools

$$
\begin{aligned}
& r=\sqrt{4 \times 16794-299 \times 217.2} \\
& r=0.677
\end{aligned}
$$

